FACTA UNIVERSITATIS

Series: Economics and Organization Vol. 14, N $\mathrm{N}^{\mathrm{o}}$ 2, 2017, pp. 117 - 126

DOI: $10.22190 /$ FUEO1702117R

Review Paper

\title{
STRUCTURAL REFORMS OF THE BANKING SECTOR - REGULATORY APPROACHES AND IMPLICATIONS
}

\author{
UDC 347.734:005.44
}

\section{Jelena Radojičić, Borko Krstić}

Faculty of Economics, University of Niš, Serbia

\begin{abstract}
This paper analyzes alternative regulatory approaches for structural reforms of the banking sector, triggered by the global financial crisis. The structural bank regulation measures proposed or adopted in several jurisdictions are based on the Volcker Rule in the United States, Vickers Commission's proposals in the United Kingdom and Liikanen Report in the EU. Despite the different approaches by legislatures, structural reforms have the same goal - a more resilient financial system. Their common element is to draw a line between commercial banking and certain investment banking activities, whose combination is seen as a source of systemic risk. Structural reforms are designed to reduce the implicit government guarantees and moral hazard of banks.
\end{abstract}

Key words: financial crisis, systemic risk, structural reform, universal bank

JEL Classification:G21, G24, G28, K22

\section{INTRODUCTION}

Global financial crisis revealed regulatory failures that have allowed the systemic risk to grow unchecked, which requires revisiting regulatory approaches. Pre-crisis capital regulation has not taken into account systemic effects (the social cost of failure). The regulatory response was raising capital requirements through Basel III and generally strengthening oversight and supervision. Capital requirements do not affect the business model. Basel measures relating to the bank size and scope are additional loss absorbency requirements for global systemically important banks and a capital surcharge of up to $2.5 \%$ imposed on banks is deemed systemically important. It turned out that failing financial institutions could not be identified on the basis of their business model. However, financial crisis has triggered a debate on the optimal size, organizational complexity, and range of activities of banks (Viñals et al., 2013)

Received March 21, 2017 / Accepted May 10, 2017

Corresponding author: Jelena Radojičić

University of Niš, Faculty of Economics, Niš, Serbia

E-mail: jelena.radojicic@eknfak.ni.ac.rs 
and a reassessment of the economic costs and benefits of universal banks' involvement in proprietary trading and other securities markets activities. Structural separation of banks, widely seen as a useful complement to traditional prudential tools, began to form part of the post-crisis regulatory agenda. The various reform proposals aim at changing how banks organize themselves. The common element of all is to draw a line between retail banking and certain types of investment banking businesses whose combination is seen as a source of systemic risk. In order to understand economic impact of regulatory reforms, it is important to pay attention to their legal attributes which reflect society's post-crisis expectation on the role of banks (Lehmann, 2014).

\section{ECONOMIC BACKGROUND ON BANK STRUCTURAL REFORMS}

The basic rationale for bank structural reforms is to insulate certain types of financial activities regarded as especially important for the real economy, or significant on consumer/depositor protection grounds, from the risks that emanate from potentially riskier but less important activities (Gambacorta and van Rixtel, 2013, p. 1). Such a separation is nothing new in the United States but for many countries, particularly for continental Europe, restrictions on universal banking would be new. Glass Steagall Act (1933) prohibited the combination of investment banking and commercial banking within one banking group. Legislation prohibited commercial banks with privileged deposit insurance coverage from engaging in securities activities, while simultaneously excluding investment banks from accepting deposits. The most important restrictions were lifted in 1999 by the GrammLeach-Bliley Act (Lehmann, 2014).

The proposed regulatory changes do not go as far as the previous strict separation. Instead of introducing structural separation, the new measures aim to prevent systemic risks by separating bank's high-risk activities, primarily proprietary trading, from its 'core' business, such as deposit-taking or retail payment services. The starting point is that the banks which combine these activities are less safe or that their failure is more expensive for the community. Universal banks became vulnerable to falling asset prices during the GFC because of the over-allocation of resources to trading and suffered dramatic losses (FSA, 2009). Also, the crisis has shown that there are some pure investment banks (e.g. Lehman Brothers or Bear Stearns), some pure retail banks (e.g. Irish banks, Northern Rock), and some universal banks (e.g. ING or RBS) who either failed or were absorbed or required exceptional government support (Fernandez-Bollo, 2013). Although evidence on the probability of failure is indirect and mixed, the general conclusion is that greater reliance on investment banking activity does not lead to lower earnings volatility, or systematic risk declining and costs of failure of universal banks can be larger, since universal banking encourages size and complexity In fact, of the 28 G-SIBs that have so far been identified by the Financial Stability Board, 20 can be classified as universal banks (Gambacorta and van Rixtel, 2013). Moreover, besides benefitting from retail deposit insurance (access to stable deposit funding, guaranteed by the state), large banks that combine trading activities with retail banking activities often benefit from their "too big to fail" (TBTF) status (implicit subsidies). TBTFs are being bailed-out by the state to prevent a failure that potentially has systemic consequences) (FSA, 2009) Thus, expectations of explicit support lead to implicit guarantees. For this reason financial regulators have focused on reforms which limit the risk of taxpayer and deposit insurance money to be used to cover losses incurred by trading activities. The goal of the reforms is to separate activities that contribute to funding the 
economy from speculative activities which will reduce the market risks that banks may take at the minimum level needed to conduct the trading activities that are necessary to finance the economy (Fernandez-Bollo, 2013).

\section{STRUCTURAL REFORMS: REVIEW AND COMPARISON}

Structural regulation of banking sector is based on the Volcker Rule (Dodd-Frank Wall Street Reform and Consumer Protection Act of 2010, sec. 619) in the United States, recommendations of the Independent Commission on Banking (chaired by Sir John Vickers) in the United Kingdom (Vickers (Chair), 2012) and the recommendations made by the HighLevel Expert Group (chaired by Erkki Liikanen) in Europe (Liikanen (Chair), 2012). Beyond this basic similarity, structural reform initiatives differ in scope (where they draw the separation line) and strictness (how thick that line is) (Gambacorta and van Rixtel, 2013) as shown in Table 1.

Table 1 Comparison of selected structural reform proposals

\begin{tabular}{|c|c|c|c|}
\hline & Volcker & Vickers & Liikanen \\
\hline & $\begin{array}{l}\text { Institutional separation } \\
\text { of commercial banking } \\
\text { and certain investment } \\
\text { activities }\end{array}$ & $\begin{array}{l}\text { Ring-fencing: structural } \\
\text { separation of activities via a } \\
\text { ring fence for retail banks }\end{array}$ & $\begin{array}{l}\text { Subsidiarisation: proprietary } \\
\text { and higher-risk trading activity } \\
\text { have to be placed in a separate } \\
\text { legal entity }\end{array}$ \\
\hline \multicolumn{4}{|l|}{$\begin{array}{l}\text { Deposit-taking institution } \\
\text { may: }\end{array}$} \\
\hline $\begin{array}{l}\text { - deal as principal in } \\
\text { securities and derivatives }{ }^{1}\end{array}$ & Not permitted & $\begin{array}{l}\text { Not permitted (but other } \\
\text { group companies may do so) }\end{array}$ & $\begin{array}{l}\text { Not permitted (but other } \\
\text { group companies may do so) }\end{array}$ \\
\hline - engage in market-making & Permitted & $\begin{array}{l}\text { Not permitted (but other } \\
\text { group companies may do so) }\end{array}$ & $\begin{array}{l}\text { Not permitted (but other } \\
\text { group companies may do so) }\end{array}$ \\
\hline $\begin{array}{l}\text { - perform underwriting } \\
\text { business }\end{array}$ & $\begin{array}{l}\text { Yes (underwriting in } \\
\text { response to client/ } \\
\text { counterparty demand) }\end{array}$ & Restricted & Permitted \\
\hline $\begin{array}{l}\text { - hold non-trading } \\
\text { exposures to other } \\
\text { financial intermediaries }\end{array}$ & Unrestricted & Restricted (inside the group) & Unrestricted \\
\hline $\begin{array}{l}\text { - investing in hedge funds } \\
\text { and private equity }\end{array}$ & Not permitted & $\begin{array}{l}\text { Not permitted (but other } \\
\text { group companies may do so) }\end{array}$ & $\begin{array}{l}\text { Not permitted (but other } \\
\text { group companies may do so) }\end{array}$ \\
\hline $\begin{array}{l}\text { Holding company with } \\
\text { banking and trading } \\
\text { subsidiaries }\end{array}$ & Not permitted & Permitted & Permitted \\
\hline Geographical restrictions & No & $\begin{array}{l}\text { Limitations for ring-fenced } \\
\text { banks in the UK to provide } \\
\text { services outside the } \\
\text { European Economic Area }\end{array}$ & No \\
\hline $\begin{array}{l}\text { Size threshold for } \\
\text { application }\end{array}$ & No & $\begin{array}{l}\text { Yes; applies to all banks and } \\
\text { building societies with } \\
\text { deposits greater than } £ 25 \\
\text { billion }\end{array}$ & $\begin{array}{l}\text { Yes; applies to all banks with } \\
\text { trading books larger than } \\
€ 100 \text { billion, or trading assets } \\
\text { more than } 15-25 \% \text { of } \\
\text { balance-sheet }\end{array}$ \\
\hline
\end{tabular}


The Volcker Rule is Part of the U.S. Dodd-Frank Act of 2010, with implementation beginning in 2015 through 2018. The Rule is narrow in scope - a prohibition of proprietary trading within the bank holding company while market-making activities on behalf of customers are allowed (Gambacorta \& Van Rixtel, 2013). Prohibited proprietary trading is defined as: engaging as principal for the trading account of a banking entity in any transaction to purchase or sell specified types of financial instruments such as securities and derivatives. Banks may invest in US bonds, underwriting, hedging activities, purchase and sale of securities for the account of its customers, investment in small enterprises, organization of private equity and hedge funds. Otherwise, the Volcker rule is quite strict. US is known for the highest level of separation in relation to other countries. The prohibition extends not only to individual banks but also to the entire banking group. The Volcker rule is introduced in the so-called Bank Holding Companies Act of 1956 (amended in 2010) and it forbids the coexistence of trading activities and other banking activities in different subsidiaries within the same group. Also, investments in hedge funds and private equity funds are not permitted, except banks are operating in accordance with the so-called "3 percent rule": (1) the ownership of a bank in these funds must not exceed 3 percent of the total outstanding ownership rights of a fund, and (2) the aggregate value of all ownership rights a banking entity holds in all funds jointly must not exceed 3 percent of its Tier-1 capital (Krahnen et al., 2016). Volcker's rules do not restrict performance of any other activity. For example, banks may invest in US bonds, underwriting, hedging activities, purchase and sale of securities for the account of their customers, investment in small enterprises, organization of private equity and hedge funds.

On the one hand, the riskiest activities (economically useless "speculation") are completely prohibited to banks. On the other hand, depository institutions may continue to offer banking services related to investment (useful banking services to clients). Thus, the universal banking model remains completely legal (Lehmann, 2014).

In United Kingdom, the Vickers Commission proposals are part of the Financial Services (Banking Reform) Act of 2013 (final regulations are expected to be fully implemented by 2019). This legislation is quite broader in scope in that they exclude a larger set of banking business from the protected entity, including also securities underwriting and secondary market purchases of loans and other financial instruments. Retail operations are separated from most market-based and non-European activities (the so-called "retail ringfence") which should help insulate UK retail banking from global shocks and ensure the supply of credit in the economy (Vickers, J. (Chair), 2011). A narrow set of retail banking business (retail deposit-taking, overdrafts to individuals and loans to small and mediumsized enterprises) must be "ring-fenced" in a separate protected entity, with limited exposure to the rest of the bank intragroup. Protected activities can coexist with others in separate subsidiaries within the same group but they are subject to tight constraints (Gambacorta and Van Rixtel, 2013). The ring-fenced entity should be isolated from the group in the sense of separation of legal and operational links. These entities can be found at the head of a bank group (it is not allowed to have any exposure to other subjects, they cannot keep the action) and they must be free to make their decision independently of the long members of the group. Transactions between a ring-fenced entity and a non-ring-fenced entity take place on a "third party basis" (separation of economic links). The proposal recommends increasing the loss-absorbing capacity of the ring-fenced entity through higher regulatory capital requirements (at least 10\% of their risk-weighted assets) (Krahnen et al., 2016). As a consequence, the depository institutions regulated by UK law will be particularly safe (Mayer Brown, 2014). 
Based on the Liikanen report, France and Germany have initiated reforms in 2013 with the aim of reorganizing the banking sector (French law no. 2013-672 of 26 July 2013 on the separation and regulation of banking activities, hereinafter: The French Act. i.e. Gesetz zur Abschirmung von Risiken und zur Planung der Sanierung und Abwicklung von Kreditinstituten und Finanzgruppen [Law concerning Separation of Risks and Restructuring and Winding-Up of Credit Institutions and Financial Groups], BGB1. 2013 I Nr. 47, 3090. hereinafter: The German Act). Measures to depository institutions restrict proprietary trading and investing in hedge and leverage investment funds are applied from the beginning of July 2015. The French and German approach follow the ring-fencing approach of the UK but, like the US, these countries have a narrower focus. Like ring-fencing in the UK, the main difference between the approaches in the US and French-German approach is that the former is based on institutional discharges and the latter on the functional separation or subsidiarization of risk activities. Legislation gives the option of performing these activities within a specific trading entity (which is separate from the retail and commercial entities) which must follow a number of rules (Lehmann, 2014):

- It must be a separate legal entity which is exclusively engaged in risky activities.

- It cannot accept deposits or provide payment services to customers.

- It has to comply with capital requirements on an individual basis.

In this way deposits will be isolated from any ill losses arising from risky activities while maintaining the ability of the banking group to conduct such a profitable activity. These measures affect only systemically important institutions, which means that not all banks are covered. Banking groups are divided into entities that receive deposits and entities engaged in the business trading where trading entities must be subsidiary and not vice versa as opposed to regulatory approach to structural changes in the UK (Lehmann, 2014).

Both the German and French legislation aim at separating speculative activities from deposit-related and customer-orientated activities but there are differences in the definition of activities that cannot deal with depository institutions and in defining the relationship between depository institutions and subsidiaries. The French legislation imposes that proprietary trading and unsecured financing to alternative investment funds above a certain threshold (the "speculative activities") must be carried out by a trading subsidiary separate from the retail banking entity (Mayer Brown, 2014). The subsidiary must have a commercial name that is distinct from that of the parent company and different managers which is not the case in Germany (Lehmann, 2014). The German legislation specifies certain high-risk activities (above a certain threshold in terms of overall trading activity), including proprietary trading, credit and guarantee business with certain alternative investment funds and certain forms of trading in one's own name with the exception of market-making that must be ring-fenced and transferred to a separate trading entity (Mayer Brown, 2014). Unlike the French Act, the German Act imposes that the subsidiary must refinance itself independently from the parent company and that transactions with other group members are to be considered as being concluded with third parties (Lehmann, 2014).

Although initiated by the Liikanen report, Legislative proposals by the European Commission on structural reforms of EU banks (submitted on 29th of January 2014) diverges to a certain extent. This proposal includes elements of the approach in the United States and individual EU states. Key points of this approach are: 
a) The Commission's proposals (European Commission, 2014) envisaged prohibition of proprietary trading in financial instruments not only for individual depository institutions but also for the parent company and its subsidiaries or banking groups (such as the Volcker rule). The Council considered that it would be better to regulate proprietary trading in a stricter way rather than to prohibit it and proposed a mandatory separation of proprietary trading from the 'core' activities of a credit institution. Investing in alternative investment funds is also prohibited, as well as holding shares in any other entity that engages in proprietary trading (Council of the European Union, 2015). The EU-style Volcker rule is limited to systemically important institutions.

b) Legislation proposed placing other high-risk trading activities (such as marketmaking risky derivatives and complex securitization) and a separate legal entity within the banking group - "subsidiarization" (such as the French and German law). Unlike Liikanen, the EU proposal does not mandatory separate trading activities from retail and commercial banking. Instead, legislation provides that national regulators would carry out risk assessment of large banks' trading activities. If a competent authority finds excessive risks, it could require those trading activities to be separated from the 'core' credit institution. Therefore, subsidiarization does not happen automatically - it is optional. A further feature of the French and German law relating to the status of trading entities. The proposal requires that trading entities must be legally, economically and operationally separate from the deposit-taking institution (Lehmann, 2014). Banking group should be formed of two different subgroups: one for basic banking activities and one for trading. Ring-fencing of commercial entities resembles the law in the UK: the trading entity's insolvency must not affect the deposit bank, the trading entity contracts with members of the group should be "length arms", the two entities' management structures should be independent and their names should be different (Lehmann, 2014).

On the basis ofthe final text of the Regulation adopted by the European Parliament and Council by June 2015, it is proposed that the proprietary trading ban would apply as of January 1, 2017 and the effective separation of other trading activities would apply as of July 1, 2018 (Mayer Brown, 2014).

To accommodate existing national rules in member states and to avoid unnecessary overlapping, the Council proposes that the member states address excessive risk-taking in banks' trading activities in one of the following two ways: 1) either through national legislation that would require large banks to ring fence their core activities, or 2) through measures that would be imposed by competent authorities in accordance with the regulation (Council of the European Union, 2015).

\section{STRUCTURAL REFORMS: COSTS AND BENEFITS}

While the structural reforms are at different stages of implementation, there is a strong ongoing discussion on what possible economic consequences (intended and unintended) are to be expected (Krahnen et al., 2016). The Table 2 provides an overview of the benefits and costs of structural banking reforms. 
Table 2 Structural reforms: costs and benefits

\begin{tabular}{|c|c|}
\hline $\begin{array}{l}\text { Benefits ensuing from } \\
\text { structural banking reform }\end{array}$ & Costs imposed by structural banking reform \\
\hline $\begin{array}{l}\text { Risk reduction } \\
\text { - } \quad \text { Lowers complexity } \\
\text { - } \quad \text { Reduces financial } \\
\quad \text { interconnectedness risk }\end{array}$ & $\begin{array}{l}\text { Implementation related costs } \\
\text { - } \quad \text { Regulatory ambiguity } \\
\text { - } \quad \text { Supervising the regime } \\
\text { - } \quad \text { Compliance burden and costs on financial institutions and } \\
\text { host country authorities }\end{array}$ \\
\hline Improving resolvability & Lower diversification benefits \\
\hline $\begin{array}{l}\text { Protection of depositor money } \\
\text { - } \quad \text { Moral hazard }\end{array}$ & $\begin{array}{l}\text { Market liquidity and borrowing costs } \\
\text { - Through impact on trading and market making } \\
\text { - } \quad \text { Through subsidiarization of universal banking group } \\
\text { (restrictions on intra-group exposures; through adverse } \\
\text { impact on cross-subsidization of businesses) } \\
\text { Risk migration to } \\
\text { - Shadow banking system, } \\
\text { - } \quad \text { Exempt institutions, } \\
\text { - } \quad \text { Other markets and countries }\end{array}$ \\
\hline
\end{tabular}

Source: Table is based on: (Krahnen et al., 2016, p.18, Viñals et al., 2013)

Structural reform contributes to financial stability by reducing complexity and interconnectedness and by facilitating lower-cost bank resolution:

- Risk reduction. The structural measures proposed by the US, UK, and EU aim to prevent systemic risks to the financial system that could be caused by the failure of large, highly complex and interconnected credit institutions. Proprietary trading is seen as a source of excessive risk-taking which is induced by an implicit subsidy from lower risk universal banking activities to higher risk market trading activities (Krahnen et al., 2016). Regulatory proposals are designed to reduce systemic risk by: shielding the institutions carrying out the protected activities from losses incurred elsewhere; preventing any subsidies from supporting the protected activities (e.g. deposit guarantee schemes) from cutting the cost of risk-taking and inducing moral hazard in other business lines and reducing complexity and possibly the size of banking organizations (Gambacorta and Van Rixtel, 2013). UK and EU proposals permit proprietary trading and high-risk investments to survive within the banking group while Volcker rule can capture benefits at the group level (Viñals et al., 2013).

- Improving resolvability. The banking supervisor, especially within a short time period, will have a difficult task to unravel the bank's loan exposures and proprietary trading exposures in a crisis situation if all lines of business are fully integrated into one corporate entity. Structural reforms could reduce complexity and facilitate better supervision, hence reducing the risk of failure and lowering resolution costs in the event of failure. (Krahnen et al., 2016, Viñals et al., 2013) Protection of taxpayers' money should be increased, as smaller failing banks can be resolved without recourse to public money. According to the European Commission, taxpayers' support for bank recapitalization, guarantees, asset relief measures and similar solutions in 2014 amounted to approximately $€ 1.6$ trillion or $13 \%$ of EU GDP. The costs of financial crises are typically very large and go far beyond the direct costs of bank bail-outs (BCBS, 2010). 
- Protection of depositor money. Deposit insurance reduces the cost of funding for banks, and reduces incentives for depositors to monitor bank's risk-taking behavior. In the absence of sophisticated and powerful deposit insurance entity, which is capable of correctly assessing bank risk-taking, trading activities splitting is the direct method of protecting banks' deposit taking business and deposit guarantee schemes (Krahnen et al., 2016).

The costs of the structural reform proposals may arise in several ways:

- Implementation related costs. Regulatory ambiguity and the blurred dividing line between proprietary trading and permitted trading can result in misidentification of permitted or prohibited activities (e.g., proprietary trading vs market making or risk hedging). This is relevant for the Volcker rule and the French and German reform proposals while Liikanen group recommends placing the market making outside the ringfence alongside proprietary trading. Significant costs arising from substantial compliance and reporting requirements apply to banks covered by the Volcker rule and also from the unwinding and decomposing integrated companies (Viñals et al., 2013).

- Lower diversification benefits. Intended effect of the reforms would be to lead to less diversified banks (diversification may be retained at the group level whenever subsidiarization is allowed) and less benefits derived from "too big to fail" status (Gambacorta and van Rixtel, 2013). Although explicit size restrictions are not part of the legislative proposals, reforms could also lead to smaller institutions (Gambacorta and van Rixtel, 2013). The results of empirical studies of economies of scale and scope in banking are not unambiguous. Although some studies point to certain benefits related to the size and diversification of the financial institutions, research generally provides confirmation of the conclusion that the major banks are riskier and that they are characterized by greater reliance on non-interest income and less stable financial structure (Bertay et al., 2013). Besides benefitting from diversification, large banks that combine trading activities with retail banking activities have access to implicit subsidies (i.e. being bailedout by the state to prevent a failure that potentially has systemic consequences) (FSA, 2009). In contrast, others hold the view that economies of scale in banking do not only exist but are significant and hence imposing limits on bank size would have unintended consequences (Mester, 2010).

- Market liquidity and borrowing costs. Banks, through proprietary trading and market making, are major providers of liquidity. Separation of some or all of trading business into a separately capitalized unit would endanger the business model of these market makers and proprietary traders and market depth and market liquidity would be reduced (Thakor, 2012; PWC (2014). This can make harder for companies to raise funds in the corporate bond markets, since reduced liquidity usually results in investors' demand for higher prices. Also, the increase in borrowing costs is driven by the rise in prices of banking products and services and the reduction in market liquidity due to retrenchment of bank activity in capital markets (PWC, 2014).

- Tightening activity restrictions on regulated banks may redistribute systemic risk. Both proprietary trading prohibition and trading separation may create additional incentives for growth of the shadow banking sector by pushing certain activities to unregulated entities where they can still exert systemic risk. This is why Vickers Commission preferred ringfencing over full separation (Viñals et al., 2013). 
Finally, banks are all starting to comply with the proposed structural reforms from different places, with different business mixes, operating models and legal entity structures. Banks could incur significant one-off costs as a result of structural separation: program management, legal and consultancy costs, finance and IT infrastructure, human resource management, procurement functions and contract novation, and re-documenting client relationship. It is estimated that EU banks affected by structural reforms could face one-off implementation of around $€ 9$ billion and additional annual costs could amount to $€ 21$ billion (PWC 2014).

\section{CONCLUSION}

The structural banking reform proposals by Volcker, Vickers and Liikanen differ substantially (which activities are to be separated, and what legal, organizational and financial restrictions will be imposed on separated activities) and they are at different stages of implementation. The main difference is reflected in the fact that there is no ban on proprietary trades outside the ring fence in the EU, while the US adopted stricter ban on banking organizations to engage in proprietary trading and restrictions on banks' participation in private funds. Although structural reforms are difficult to implement and coordinate internationally and although they are costly for financial institutions, their implementation can lead to direct financial stability benefits (Gambacorta and van Rixtel, 2013). The structural banking regulations specify a regulatory framework that creates preconditions for strengthening the connection between banking services and the real economy by protecting those services critical for the real economy (socially important retail banking activities) from excessively risky speculative trading activities. This paradigm shift from trading activities towards traditional core banking business is a reflection of post-crisis view of banks' emphasized social role.

\section{REFERENCES}

BCBS (2010). An Assessment of the Long-Term Economic Impact of Stronger Capital and Liquidity Requirements. Basel: Bank for International Settlements.

Bertay, A. C., Demirgüç-Kunt, A. and Huizinga, H. (2013). Do we need big banks? Evidence on performance, strategy and market discipline. Journal of Financial Intermediation, 22(4), 532-558.

Council of the European Union (2015) Proposal for a Regulation of the European Parliament and of the Council on structural measures improving the resilience of EU credit institutions. Retrieved from: www.consilium.europa.eu/en/press/press.../st10150-en15_pdf/

Dodd-Frank Wall Street Reform and Consumer Protection Act of 2010. Publ. L. 111-203, 124 Stat. 1376. Retrieved from: https://www.sec.gov/about/laws/wallstreetreform-cpa.pdf

European Commission (2014). Proposal for a Regulation of the European Parliament and of the Council on structural measures improving the resilience of EU credit institutions 2014/0020 (COD) Retrieved from: http://eur-lex.europa.eu/legal-content/EN/TXT/PDF/?uri=CELEX:52014PC0043\&from=EN

Fernandez-Bollo É. (2013). Structural reform and supervision of the banking sector in France. OECD Journal: Financial Market Trends, Vol. 2013/1. DOI: http://dx.doi.org/10.1787/fmt-2013-5k41z8t3mrhg.

Financial Services (Banking Reform) Act (2013) Retrieved from: at http://www.legislation.gov.uk/ukpga/ . 29FL02 2013/33/pdfs/ukpga_20130033_en.pdf.

Financial Services (Banking Reform) Act of 2013 (c. 33). Available at hfttp://www.legislation.gov.uk/ukpga/ 2013/33/pdfs/ukpga_20130033_en.pdf 
FSA (2009) The Turner Review, A Regulatory Response to the Global Financial Crisis, 28. Financial Services Authority. Retrieved from: https://www.researchgate.net/deref/http\%3A\%2F\%2Fwww.fsa.gov.uk \%2Fpubs\%2Fother\%2Fturner_review.pdf

Gambacorta, L., and A. Van Rixtel (2013). Structural bank regulation initiatives: approaches and implications. BIS working paper No. 412. Basel: Bank for International Settlements.

Gesetz zur Abschirmung von Risiken und zur Planung der Sanierung und Abwicklung von Kreditinstituten und Finanzgruppen v. 7.8.2013, BGB1. 2013 I p. 3090. Retrieved from: http://www.bundesgerichtshof.de/ SharedDocs/Downloads/DE/Bibliothek/Gesetzesmaterialien/17_wp/Abschirmung_Risiken/bgbl.pdf?_blo $\mathrm{b}=$ publicationFile

Krahnen, J.-P., Noth, F., and Schüwer, U. (2016). Structural Reforms in Banking: The Role of Trading. SAFE White Paper No. 33/2016. Frankfurt: The Research Center SAFE (Sustainable Architecture for Finance in Europe).

Lehmann, M. (2014.).Volcker Rule Ring-Fencing or Separation of Bank Activities: Comparison of Structural Reform Acts Around the World. LSE Law, Society and Economy Working Papers 25/2014, 2.

Liikanen, E. (Chair) (2012) The High-Level Expert Group on Reforming the Structure of the EU Banking Sector: Final Report. Retrieved from: at http://ec.europa.eu/internal_market/bank/docs/high-level_expert_group/ report_en.pdf

Loi no. 2013-672 du 26 juillet 2013 de séparation et de régulation des activités bancaires, J.O. n 173 du 27 juillet 2013, p. 12530.. Retrieved from: https://www.legifrance.gouv.fr/affichTexte.do?cidTexte=JORFTEXT 000027754539

Mayer Brown (2014). Legal Update, February 2014. Retrieved from: https://www.mayerbrown.com /files/Publication/f6722a7a-b666-4384-931f-0f77d6424e37/Presentation/PublicationAttachment/1a249a85-301543eb-8389-26237a62e419/update_volcker_vickers_feb14.pdf

Mester, L. (2010). Scale economies in banking and financial regulatory reform, The Region, [Federal Reserve Bank of Minneapolis] 24(3): 10-13.

PWC (2014). Impact of bank structural reforms in Europe Report for AFME (Association for Financial Markets in Europe). Retrieved from: http://www.pwc.com/il/he/bankim/assets/pwc-study-impact-of-bank-structuralreform.pdf

Thakor, A. V. (2012). The Economic Consequences of the Volcker Rule. U.S. Chamber of Commerce Center for Capital Markets Competitiveness. White Paper Summer 2012.

Vickers, J. (Chair) (2011). Final Report of the Independent Commission on Banking. Retrieved from: http://www.ecgi.org/documents/icb_final_report_12sep2011.pdf

Viñals J., Pazarbasioglu C., Surti J., Narain A., Erbenova M., Chow J. (2013). Creating a safer financial system: Will Volcker, Vickers, and Liikanen structural measures help? IMF Staff Discussion Note, May. Washington: International Monetary Fund.

\section{STRUKTURNE REFORME BANKARSKOG SEKTORA - REGULATORNI PRISTUPI I IMPLIKACIJE}

Rad analizira alternativne regulatorne pristupe strukturnim reformama bankarskog sektora, koje je pokrenula globalna finansijska kriza. Strukturna regulacija banaka, predložena ili usvojena u više jurisdikcija, bazira se na Vokerovom pravilu u SAD, predlozima Vickers komisije u UK $i$ Liikanen izveštaju u EU. Uprkos različitim pristupima zakonodavaca, strukturne reforme imaju isti cilj-otporniji finansijski sistem. Zajednički element je povlačenje linije između komercijalnog bankarstva i određenih aktivnosti investicionog bankarstva, čija se kombinacija percepira kao izvor sistemskog rizika. Strukturne reforme su dizajnirane da umanje implicitne državne garancije i moralni hazard banaka.

Ključne reči: finansijska kriza, sistemski rizik, strukturne reforme, univerzalna banka 